\title{
EFL Teachers' Emotional Intelligence, Emotional Support, and Their Classroom Leadership: A Structural Equation Modeling Approach
}

\section{Reza Khani ${ }^{1} \&$ Fian Ghasemi ${ }^{1 *}$}

* Correspondence:

fian.ghasemi@yahoo.com

1. Department of English Language and

Literature, Ilam University, Iran

Received: 24 November 2018

Revision: 8 February 2019

Accepted: 8 April 2019

Published online: 20 September 2019

\begin{abstract}
This study is aimed to investigate the relationship between teacher emotional intelligence, emotional support, and classroom leadership. To this end, three instruments consisting of emotional intelligence with three dimensions (appraisal and expression of emotion, the regulation of emotion, and the utilization of emotion), teacher emotional support scale with four dimensions (positive climate, negative climate, teacher sensitivity, and regards for student perspective), and teacher classroom leadership scale with seven dimensions (idealized influence, inspirational motivation, individual consideration, intellectual stimulation, contingent reward, active management, and passive management), were administered to $321 \mathrm{EFL}$ Iranian teachers in Ilam, Iran. Bivariate correlation analysis indicated significant correlations among all three variables. Not only were all of the subscales correlated with their scales but also significant correlations were found among them and other scales and subscales of the study. Moreover, Structural Equation Modeling (SEM) approach was applied in order to confirm the hypothetical model. The following results obtained from SEM confirmed the hypothetical model (chi- squared $=1 / 637$, ( $p<.001$ ), PGFI $=0.693(>0.50)$, and PNFI $=0.785(>0.50)$, IFI $=0.981(>0.90)$, CFI $=0.981$ $(>0.90), \mathrm{SRMR}=0.031(<0.05), \mathrm{GFI}=0.947(>0.90)$, and RMSEA $=0.041(<$ $0.05)$. The results showed that being aware of emotional skills and leadership behaviors, teachers and student teachers could better develop effective leadership skills in the class. The results of the present study have valuable implications for EFL teachers and other practitioners in the field.
\end{abstract}

Keywords: classroom leadership, emotional intelligence, emotional support, EFL teachers 


\section{Introduction}

Classroom teachers are the most important individuals who affect students' achievements outside their home. Their expertise can affect teaching practices in class. Their assessment of students' progress depends on their understanding of learning (Darling-Hammond, 1997). There is an extensive literature on variables that affect ELT teacher's performance and success in ELT classes and in relation to students. These variables vary from cognitive factors, philosophy, policy making, and teachers' own characteristic to other variables. The variables that are considered to play an important role in the successes and failure of both teachers and students and other practitioners in the field are emotional variables such as emotional intelligence and emotional support. These variables in turns if observed well will affect teacher performance including teacher leadership style in the class and in what follows these variables. With regard to English language teaching (ELT), teachers need to develop certain qualities so that they can help students to learn the language more effectively. Among the various influential factors that affect the performance of students in ELT classrooms, teachers' emotional intelligence, emotional support, and their classroom leadership stand out.

As long as emotional intelligence (EI) is considered as an important competence for all individuals in different positions especially in leadership, leaders need to understand the concept and develop their own EI and provide opportunities for helping individuals to develop their professional development (Murray \& Christison, 2008). With regard to teachers and students, teachers as leaders need to possess certain kills and abilities to develop students' emotional and social skills. In the last decade, emotional intelligence has been known as one of the key elements of leadership in many different contexts. In educational context, teachers with high level of emotional intelligence are more likely effective leaders in understanding and managing their own and their students' emotions. They are more able to deal with challenging situations such as students' feelings of anger and help them to adapt themselves to various situations (Lordanoglou, 2007).

Teachers need to understand the relationship between emotions and leadership in order to provide an appropriate level of support for their students in the class and may eliminate the problems that they may face in class. Individuals who receive emotional support are happier and stabilize their relationships with others. They are capable to apprehend others' emotions and feelings and deal with different characteristics of emotional intelligence such as kindness and affection (Atoum \& Al-Shoboul, 2018). Depending on a particular personality, children can develop their emotional support skills from adolescences' emotional support. By observing and imitating parents and other adolescences, children learn how and when to support others emotionally (Pierce, Sarason, \& Sarason, 1996). Examining the relationship between children who receive emotional support from parents and their health in adolescence, Shaw, Krause, Connel, and Dayton (2004) found out that parents' emotional support in early life was strongly associated with increased level of depression in adulthood. Children who receive adequate emotional support from adults are less likely to suffer from the mental and physical disease than children who receive less emotional support than their parents did.

Emotional support was related to various emotional intelligence factors. Radi (2002) conducted a study in order to investigate the relationship between parental cruel treatment and their negligence of children's cognitive, emotional, and social intelligence. The results indicated that parents' abuse and negligence were negatively related to children's cognitive, emotional, and social intelligence. Investigating the relationship between emotion and social intelligence and the social support network among young people, Ukaegbu (2015) found a positive correlation between emotional and social support among young people.

\subsection{Statement of the Problem}

The relation between teacher emotional intelligence, emotional support, and classroom leadership has not already been investigated in the literature. Therefore, a better understanding of this relationship could lead to better preparation of teachers in English language teaching and an improvement in teachers' practices as EFL teachers who attempt to improve their skills in EFL classrooms. By investigating the possible relationship among the variables of the present study, the researchers attempted to make contribution to existing body of research both at the theoretical and practical levels. At the theoretical level, it would help to develop a deeper view of the concepts of teacher emotional support and classroom leadership, especially in English language teaching. 
At the practical level, it would provide evidence for the association between these variables with regard to learning context and the extent of teacher emotional support and leadership offered to ELT learners. It would also help EFL teachers to be more aware of their emotional skills and leadership behaviors and their effect on EFL learners' language learning; this awareness can help learners to experience more pleasurable language learning environments. Understanding this relationship would help teachers to create a productive environment for their students and enhance their language learning.

A growing body of research has been conducted on each of these variables separately. Moafian and Ghanizadeh (2009) examined the relationship between Iranian EFL teachers' emotional intelligence and their self-efficacy in Language Institutes. Selecting 89 EFL teachers from different Language Institutes in Mashhad, the researchers asked the participant to complete the "Teachers' Sense of Efficacy Scale" and the "Emotional Intelligence Questionnaire." The results of the study showed a significant relationship between the teachers' emotional intelligence and their selfefficacy. Three components of emotional intelligence including emotional self-awareness, interpersonal-relationship, and problem-solving were found to be good predictors of teacher self-efficacy. Investigating the relationships between emotional intelligence and teacher burnout in a sample of 167 Chinese secondary school teachers in Hong Kong, Chan (2006) suggested that emotional exhaustion affected by emotional appraisal and positive regulation, was causally prior to depersonalization and personal accomplishment, but personal accomplishment could develop relatively independently from the burnout components through the influence of positive utilization of emotions.

Yeung and Leadbeater (2010) conducted a longitudinal study to examine the associations between peer victimization and emotional and behavioral problems among 580 adolescents. They suggested that the higher levels of father and teacher emotional support decrease the levels of adolescents' emotional and behavioral problems. The higher levels of mother emotional support resulted in lower levels of emotional problems. Teacher emotional support moderated the link between relational victimization and emotional and behavioral problems across time.

In another study, Bolkan and Goodboy (2009) reported a positive correlation between teachers' transformation leadership skills and their students' learning achievement. They concluded that teachers with transformational leadership skills need to focus on students' need. Teachers with high idealized influence and individualized consideration are vigorous in encouraging their students about learning and achievement. Therefore, the present study focuses in depth on the relationship between teacher emotional intelligence, emotional support and their classroom leadership in an EFL classroom setting. To this end, in the following lines, the variables, questions, and hypotheses are elaborated at length both individually and in relation to other variables.

\subsection{Research Questions of the Study}

Accordingly, the present study elaborates on this issue by answering the following questions:

1. Is there a significant relationship between the emotional intelligence and classroom leadership (CL) of EFL teachers?

2. Is there a significant relationship between the emotional support (ES) and Classroom leadership (CL) of EFL teachers?

3. Is there a significant relationship between emotional intelligence and emotional support ?

\subsection{Hypotheses of the Study}

Based on the research questions, the following hypotheses were formulated:

Null Hypothesis 1: There is a significant relationship between EFL teachers' emotional intelligence and their classroom leadership .

Null Hypothesis 2: There is no significant relationship between EFL teachers' emotional support and classroom leadership .

Null Hypothesis 3: There is no significant relationship between EFL teachers' emotional intelligence and their emotional support.

The initial hypothesized model of the associations between the main variables is shown in the following figure. 


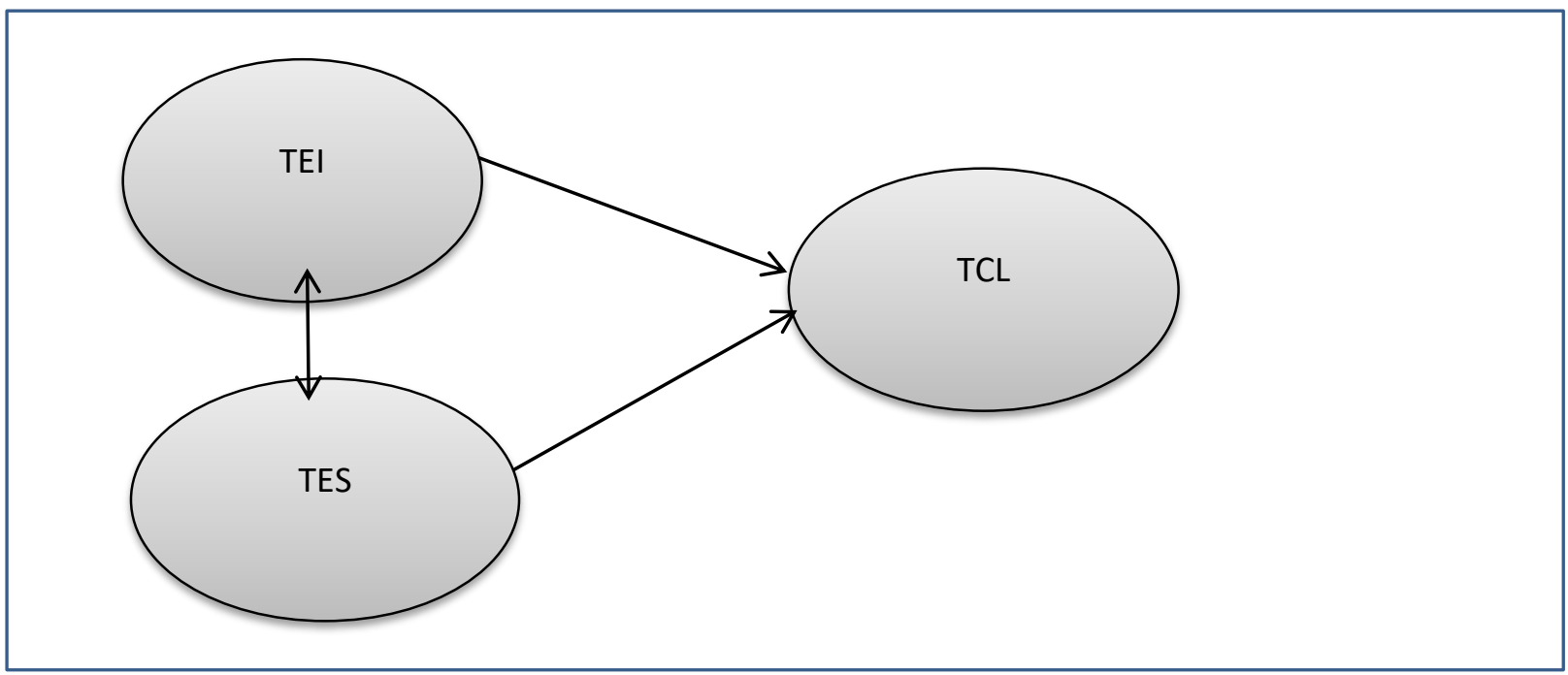

Figure 1. The hypothesized model of the associations between the main variables TEI=teacher emotional intelligence, $\mathrm{TCL}=$ teacher classroom leadership, $\mathrm{TES}=$ teacher emotional support

\section{Literature Review}

\subsection{Emotional Intelligence}

Salovey and Mayer $(1990,2007)$ define emotional intelligence as a branch of social intelligence. It refers to individuals' ability to deal with their emotions. They believe that emotional intelligence supports a course of "personal investigation that can occur in various contexts such as politics, ethnicity, religion, and other characteristics rather than focusing on the outcome" (Mayer \& Salovey, 1997, p.41). In addition, they stated that emotional intelligence is measurable. Their original framework describes skills that consider different aspects such as evaluation and expression of emotions, the regulation of emotions, and the use of emotions to motivate and achieve. Facilitation of thought was not addressed in this framework. Later, it has been found that people have the ability to recognize their emotions and the emotions of others (Mayer \& Salovey, 1997).

In providing other definition for emotional intelligence, Mayer and Salovey (1997) view emotional intelligence as an ability to perceive, appraise, and express emotion accurately; access and/or produce feelings; understand emotion and emotional knowledge; and regulate emotions to promote emotional and intellectual growth. Their theory of emotional intelligence is known as an ability model that processes emotional information. The two components of this model are experiential and strategic which include four branches. The experiential part includes the identification of emotions and the use of emotions. The strategic part includes the understanding of emotions and managing emotions (Mayer \& Salovey, 1997) .

These branches were organized from basic psychological processes to higher processes. The first branch, identifying emotions, involves the abilities to recognize emotions in self and in others, express them accurately and distinguish between accurate and inaccurate feelings. This self-awareness and emotional awareness, as well as the accuracy of perception and judgment, are emphasized in this branch (Caruso, 2008; Mayer \& Salovey, 1997; Salovey \& Mayer, 2007). The second branch includes the use of emotions to facilitate the process of thought. It refers to the abilities that redirect and categorize feelings, to produce emotions that are important in making judgment and memory processes, to take advantage of mood changes, to understand various perspectives, and to use emotional states to solve problems and being creative. This branch emphasized the use of emotions in the process of thoughts (Caruso, 2008; Mayer \& Salovey, 1997; Salovey \& Mayer, 2007).

The third branch, emotional understanding, consists of recognizing emotional causes and consequences; understanding relationships and complex feelings; combining emotions; identifying different states of emotions, and understanding change among emotions. The language of emotions is important in this branch. That is, individuals can express their emotions using a wide range of emotional vocabulary (Caruso, 2008; Mayer \& Salovey, 1997; Salovey \& Mayer, 2007). The fourth branch of this model is emotional management which consists of the abilities to acknowledge pleasant and unpleasant feelings and to manage emotions in self and others. The ability to manage an emotional state 
by being involved in it, extending it, or separating from it is also important in this branch. These abilities within this model develop in order, starting with identifying feelings and end with managing feelings (Caruso, 2008; Mayer \& Salovey, 1997; Salovey \& Mayer, 2007).

A number of researchers have investigated the relationship between emotional intelligence and health (Brackett $\&$ Mayer, 2003 ), social skills (Schutte, Malouff, Bobik, Coston, Greeson, Jedlicka, Rhodes, \& Wendorf, 2001), job satisfaction (Abraham, 2000), transformational leadership (Gardner \& Stough, 2002), gender (Alonso \& Viswesvaran, 2005; Barchard \& Hakstian, 2004; Perry, Ball, \& Stacey, 2004; Schaie, 2001), and age and experience (Atkins \& Stough, 2005; Day \& Carroll, 2004; Schaie, 2001).

\subsection{Emotional Support}

Having an effective classroom practice, teachers need to support their students socially and emotionally (Pianta \& Hamre, 2009). According to researchers' definition of emotional support (Albrecht \& Adelman, 1987; Burleson, 1984; Burleson, 2003; Cutrona \& Russell, 1990), it has been defined as one's ability in understanding others' emotional needs, showing care and concerns, supporting others emotionally, helping distress people, listening to them, and empathizing with and exploring their feelings (Burleson, 1984). With regard to teacher and student relationship, emotional support involves teachers to display their concerns and cares for the students, their respect for the students, their willingness to understand students' feelings and opinions (Patrick, Anderman, \& Ryan, 2002; Pianta \& Hamre, 2009).

The two theories including attachment theory (Ainsworth, Blehar, Waters, \& Wall, 1978) and self-determination theory (Ryan \& Deci, 2000; Skinner \& Belmont, 1993) form the bases of most of the studies on emotional support in classrooms. The former asserts that if parents support their children emotionally, they help children to be independent and risk taker (Ainsworth et al., 1978). The latter examines an individual's willingness to promote their psychological needs such as self-motivation. Three important needs that facilitate individuals' growth, integration, and social development are competence, relatedness, and autonomy. Social environments play an important role in promoting or preventing these needs. Therefore, individuals' development will be facilitated if environments support individuals' autonomy, competence, and relatedness. However, individuals' development will be prevented if environments control individuals' behavior and neglect responding to their needs (Ryan \& Deci, 2000). With regard to school, teachers can develop students' competency, relatedness, and autonomy so that they can be motivated and learn more effectively (Roeser, Eccles, \& Sameroff, 1998). Teachers can enhance students' motivation and engagement in a class by encouraging them to complete a task, supporting them, and explaining clearly what they want from students (Wentzel, 1999).

Using various observational methods, a number of researchers have examined teachers' emotional support in relation to students' interaction, social behaviors, and their motivation and academic outcome (Allen, Gregory, Mikami, Lun, Hamre, \& Pianta, 2013; Downer, López, Grimm, Hamagami, Pianta, \& Howes, 2012, Khany \& Ghasemi, 2018; Hamre \& Pianta, 2005; Merritt, Wanless, Rimm-Kaufman, Cameron, \& Peugh, 2012; Pianta, Howes, Burchinal, Bryant, Clifford, \& Early, 2005; Pianta, Belsky, \& Houts Morrison, 2007; Ruzek, Hafen, Allen, Gregory, Mikami, \& Pianta, 2016).

\subsection{Classroom Leadership}

Not only teachers must be involved in leadership at school level (Pounder, 2006), they must also be involved in classroom leadership. The term classroom leadership is defined as teachers' activities in creating a supportive environment that promotes both academic and social-emotional learning (Ertesvåg, 2009). These activities include building a supportive relationship with students, organizing their teaching, and monitoring students' activities (Bru, Murberg, \& Stephens, 2001; Doyle, 1986; Good \& Brophy, 2007; Hughes, 2002; Roland, 1999; Thuen, 2007). The rapport between teacher and students in class is an essential component of classroom leadership (Ertesvåg, 2009). Considering this relationship from an organizational perspective, Cheng (1994) considered classroom as a small social organization in which the teacher is a leader and students are followers. A number of studies (Bolkan \& Goodboy, 2009, 2010; Luechauer \& Shulman, 2002; Pounder, 2003, 2006, 2008; Wilmore, 2007) support Cheng's view of the teacher as a leader in class. Among many theories that have been developed in the field of leadership, transactional and transformational leadership theories have been used frequently in educational research over the past decades (Hallinger, 2003), particularly in the field of English language education (Christison \& Murray, 2012). A number of 
studies supported their applicability in the classroom context (Baba \& Ace, 1989; Bolkan \& Goodboy, 2009, 2010; Cheng, 1994; Leithwood \& Jantzi, 2006; Pounder, 2003, 2006, 2008).

Examining the effect of transformational leadership theories in the university classrooms, several studies have found a positive and significant relationship between different dimensions of these theories and student willingness to put in extra effort, classroom leadership effectiveness, and student satisfaction with classroom leadership (Ojode, Walumbwa, \& Kuchinke, 1999; Pounder, 2008; Walumbwa, Wu, \& Ojode, 2004). The same results were found in Walumbwa and Ojode's (2000) study in which female students rated their classroom teachers higher on transformational leadership dimensions than did male students. Harvey, Royal, and Stout (2003) also suggested a positive relationship between transformational leadership dimensions namely charisma, intellectual stimulation, individualized consideration, and intellectual stimulation and an instructor's performance and student involvement in a university classroom context. Pounder (2006) argues that transformational leadership theory could be considered as one of the defining qualities of a teacher leader and could include both school and university contexts. Classroom leadership has been examined in relation to students in educational setting such as classroom (Baba \& Ace, 1989; Bolkan \& Goodboy, 2009, 2010; Cheng, 1994; Harvey, Royal, \& Stout, 2003; Leithwood \& Jantzi, 2006; Khany \& Ghoreyshi, 2013; Ojode, Walumbwa, \& Kuchinke, 1999; Pounder, 2003, 2006, 2008; Walumbwa \& Ojode, 2000; Walumbwa, Wu, \& Ojode, 2004).

\subsection{Emotional Intelligence and Leadership}

Goleman (1998) refers to the importance of high touch ability in leadership and management. These abilities are also essential in order to lead more effectively in the field of language education (Murray \& Christison, 2008). It "involves the ability to empathize, to understand the subtleties of human interaction, to find joy in one's self and to elicit it in others, and to stretch beyond the quotidian in pursuit of purpose and meaning" (Pink, 2005, p.52). All individuals in different positions particularly in leadership position need to develop their emotional competence in order to be successful. It is learned capability based on emotional intelligence that results in outstanding performance at work. Although emotional competence and EI are related, they are different in that emotional competence is formed based on emotional intelligence (Goleman, 1998). Regarding Goleman's theories as a tool for evaluating leaders' performance, leaders need to understand the two components of emotional competence including personal competence and social competence (Murray \& Christisin, 2008).

Personal competence refers to how individuals can manage themselves. It includes self-awareness, self-regulation, and motivation. The first aspect of personal competence is self-awareness which refers to individuals' ability in knowing their own internal states, preferences, resources, and intuitions (Murray \& Christisin, 2008). This selfreflection is also essential in the field of language teaching because it leads to change in teaching practice (Richards \& Lockhart, 1994). Leaders can learn by reflecting on their own practices. Self-confidence is also crucial in leadership. Leaders who lack self-confidence cannot make effective decisions. In contrast, leaders with high self-confidence can make effective decisions and implement them despite their difficulties (Murray \& Christisin, 2008).

The second aspect of personal competence is self-regulation. It refers to the ability of individuals who manage their internal states, impulses, and resources. Leaders need to be able to regulate their emotions and use them positively. They need to control their disruptive emotions that negatively affect others in the workplace. By controlling disruptive emotions, leaders can deal with stress at work. They can lead successfully in various situations by building trust among others. They also need to set an example in the workplace by admitting their mistakes, following promise, and being a careful and trustworthy person. They also need to be flexible and create an opportunity for creativity among individuals (Murray \& Christisin, 2008).

The third aspect of personal competence is motivation. It refers to individuals who have the emotional tendencies that guide and facilitate achieving goals. All effective leaders are internally motivated to achieve certain goals. With regard to English language teaching, leaders are constantly involved in learning and committing themselves to the goals of the organization. They also need to exercise performance management to ensure that organizational work meets the high standards of teaching. They are actively involved in finding new ways of doing things. Optimism is a crucial characteristic in successful leading. Leaders act based on their feeling that their goals are achievable. They consider obstacles as a normal and search to find ways to solve the problem (Murray \& Christisin, 2008). 
Social competence, the second component, refers to the ability that helps individuals to control relationships. They need to be aware of others' feelings, needs, and concerns, help others to develop themselves and understand others. Effective leaders attempt to understand the strengths and weaknesses of their followers. By mentoring others' performance, leaders try to work on their weaknesses and improve them (Murray \& Christison, 2008). Mentoring has been observed to be effective in language teaching situations (Wallace, 1994). Effective leaders recognize their important role and try to improve teaching and learning (Murray \& Christisin, 2008).

Over the last few decades, several studies (Caruso, Salovey, \& Mayer, 2003; Ciarrochi, Chan, \& Caputi, 2000; George, 2000; Lordanoglou, 2007; Moss et al., 2006; Prati, Douglas, Ferris, Ammeter, \& Buckley, 2003; Wolff, Pescosolido, \& Druskat, 2002; Wong \& Law, 2002) have examined the relation between emotional intelligence and leadership effectiveness and the findings of their paper indicated that emotional intelligence has been found as one of the important components of leading effectively in many different contexts. The association between these two variables has been supported in several studies. For example, investigating the link between emotional intelligence and mood, Ciarrochi et al. (2000) found that leaders with high emotional intelligence can better manage mood. Not only they are aware of their moods, but also they are also aware of how they react and behave toward these moods. This awareness may lead them to reconsider their decisions and the results of their decision that are based on their positive and negative mood may negatively or positively be affected by their mood. George (2000) pointed out that when leaders are in a pessimistic mood, they may make a decision that may have led them to apply the negative approach to the problem. They need to reconsider the problem and solution. Similarly, when leaders are in an optimistic mood, they may consider the problem in an unrealistic way. Moreover, other studies (Feyerherm \& Rice, 2002; Kerr, Garvin, Heaton, \& Boyle, 2006; Rosete \& Ciarrochi, 2005; Wong \& Law, 2002; Zhou \& George, 2003) have also found that emotional intelligence and leadership are relatively related.

\section{Methodology}

\subsection{Design of the Study}

The design of the study is correlational, using a structural equation modeling approach to investigate the relationship between teachers' emotional intelligence, emotional support, and classroom leadership.

\subsection{Participants}

The target population of this study was 321 teachers (female $=242$, male $=77$ ) from high schools, middle schools, and English language learning institutions. All the participants were EFL teachers who taught English in middle schools, high schools, and English language learning institutions in Ilam province, Iran. After selecting the schools and English language learning institutes, the researchers personally collected the data from EFL teachers in each school and institute. Only EFL teachers were asked to participate. Each of 321 EFL teachers completed the questionnaires. Most participants were females (75.9\%). Participants ranged in age from 21 to 53, with an average age of 24.19 years $(\mathrm{SD}=6.19)$. The majority of the teachers taught either in English language learning institutions (56.8.\%) or in high school (25.0\%). Only $17.9 \%$ of them taught in middle schools. Most teachers have had either Bachelors $(22.5 \%)$ or Masters $(61.1 \%)$ degrees, with a few who have had a Doctorate degree $(16.0 \%)$. Teachers' experience of teaching ranged from one to 25 years, with a mean of 4.51 years $(\mathrm{SD}=3.01)$.

\subsection{Instruments}

Three questionnaires were used in the present study including emotional intelligent, teacher emotional support scale, and teacher classroom leadership scale.

\subsubsection{Emotional Intelligence Questionnaire}

Schutte et al. (1998) developed a questionnaire based on the theoretical model of emotional intelligence developed by Salovey and Mayer (1990). Each item reflected a different aspect of emotional intelligence within the framework of the model. Respondents used a 5-point scale, on which a "1" represented "strongly disagree" and a "5" represented "strongly agree," to indicate to what extent each item described them. All parts of the model were represented by multiple items. In this set, 33 items represent different categories of the model which include 13 of the items for the appraisal and expression of emotion category of the model, 10 of the items for the regulation of emotion category of the model, and 10 items for the utilization of emotion category of the model. An alpha coefficient of .935 supported the high internal reliability of the instrument. 


\subsubsection{Teacher Emotional Support Scale (TESS)}

Teacher emotional support scale was developed by Khany and Ghasemi (2018). The scale includes 27 items which consist of four dimensions including positive classroom climate ( 8 items), negative classroom climate (4 items), teacher sensitivity (7 items), and regards for students' perspective ( 8 items). Respondents used a 5 -point scale, on which a " 1 " represented "strongly disagree" and a " 5 " represented "strongly agree." The internal consistency of the whole instrument was found to be relatively high (Cronbach's alpha $=.833$ ).

\subsubsection{Teacher Classroom Leadership SCALE (TCLS)}

Teacher classroom leadership scale was developed by Khany and Ghasemi (2019). The scale includes 32 items which consist of 7 dimensions including idealized influence (5 items), inspirational motivation (4 items), individual consideration (5 items), intellectual stimulation (5 items), contingent reward (5 items), active management (5items), and passive management (3 items). Respondents used a 5-point scale, on which a "1" represented "strongly disagree" and a "5" represented "strongly agree." The internal consistency of the whole instrument was found to be very high (Cronbach's alpha $=.928)$.

\subsection{Data Collection}

The study was conducted using a quantitative methodology of data collection and analysis. Two separate phases of data collection were included in this study. The first phase of the data collection included the development and validation of teacher emotional support scale and teacher classroom leadership scale. The second phase of data collection included the administration of three questionnaires of emotional intelligence, teacher emotional support, and ELT teacher classroom leadership to 321 EFL teachers who taught in high schools, middle schools, or English language learning institutions in Ilam- Iran. During all phases of data collection, the teachers were given enough time to answer the questions. Moreover, teachers' identities and confidentiality were ensured.

\subsection{Data Analysis}

The data were screened for detecting any missing values. Less than five missing data were replaced with the median for ordinal scale. The descriptive analysis of EFL teachers' teaching the English language was carried out with SPSS version 23. SEM was also conducted using AMOS 22. SEM was used to test the measurement and structural models of all hypothesized relations among constructs. The correlations among the main variables would be determined after the hypothesis testing by using SEM. The statistics used to examine model fit were the chi-square statistic, the Parsimony Goodness-of-Fit Index (PGFI), the Parsimonious Normed Fit Index (PNFI), test of absolute fit including Goodness-of-Fit Index (GFI), Adjusted Goodness of Fit Index (AGFI) and the Root Mean square Error of Approximation (RMSEA), as well as test of Incremental Fit Index (IFI), and Comparative Fit Index (CFI). In general, Chi-squared statistic of less than 3, with GFI and AGFI greater than .90 and .85 respectively and RMSEA of Less than .6 are considered as an adequate model fit (Hu \& Bentler, 1999). Regarding PGFI and PNFI, no threshold levels have been suggested for these indices. It is possible to obtain parsimony fit indices within the .50 region while other goodness of fit indices obtains values over 90 (Mulaik et al., 1989).

\section{Results}

In the following sections, the results of data screening, descriptive statistics, and evaluation of the model are presented in details.

\subsection{Data Screening}

The data were screened for detecting any missing data. $20 \%$ missing-value criterion as suggested by Karanja, Zaveri, and Ahmed (2013) was used in order to deal with missing values in the data. Variables with missing values were found in the data analysis. Less than five percent of missing data were replaced with the median for the ordinal scale .

\subsection{Results of Descriptive Statistics}

The results of the descriptive statistics indicated that the mean scores of the main variables ranged from 2.53 to 3.91 . The standard deviation ranged from .71 to 1.03 . 
Table 1. Descriptive statistics for all measures

\begin{tabular}{llllll}
\hline Variables & $\mathrm{N}$ & Mean & SD & Skewness & Kurtosis \\
\hline EI1 & 308 & 2.73 & .83 & .29 & -.39 \\
EI2 & 308 & 2.86 & .89 & .10 & -.80 \\
EI3 & 308 & 2.72 & .88 & .29 & -.47 \\
EI4 & 308 & 3.09 & .91 & -.28 & -.68 \\
EI5 & 308 & 2.99 & .94 & -.08 & -.88 \\
EI6 & 308 & 3.03 & .95 & -.10 & -.92 \\
PC7 & 308 & 2.65 & .97 & .27 & -.79 \\
NC8 & 308 & 3.24 & .96 & -.42 & -.70 \\
TS9 & 308 & 2.53 & .99 & .43 & -.43 \\
RSP10 & 308 & 2.67 & 1.03 & .30 & -.87 \\
II11 & 308 & 3.75 & .76 & -.73 & 1.01 \\
IM12 & 308 & 3.88 & .72 & -.89 & 1.89 \\
IC13 & 308 & 3.88 & .74 & -.62 & .98 \\
IS14 & 308 & 3.75 & .76 & -.72 & .98 \\
CR15 & 308 & 3.75 & .71 & -.67 & 1.03 \\
AM16 & 308 & 3.91 & .81 & -.71 & .62 \\
PM17 & 308 & 3.82 & .74 & -.52 & .73 \\
\hline
\end{tabular}

Note. EI=emotional intelligence; $\mathrm{PC}=$ positive classroom; $\mathrm{NC}=$ negative classroom; $\mathrm{TS}=$ teacher sensitivity, $\mathrm{RSP}=$ regards for students' perspective; $\mathrm{II}=$ idealized influence; $\mathrm{IM}=$ inspirational motivation; $\mathrm{IC}=$ individual consideration; $\mathrm{IN}=$ intellectual stimulation; $\mathrm{CR}=$ contingent reward; $\mathrm{AM}=$ active management; $\mathrm{PM}=$ passive management

Bivariate correlation analysis indicated significant correlations among all three variables (Table 2). As can be seen in Table 2, all three variables were positively correlated with each other. They were all significant at $p<.01$. As can be seen in Table 2, significant correlations were found among all the variables of the study. Not only all of the subscales were correlated with their scales but also significant correlations were found among them and other scales and subscales of the study. Strong positive correlations were found between the main variables of the study. 
Table 2. Correlation matrix of all the scales and sub-scales

\begin{tabular}{|c|c|c|c|c|c|c|c|c|c|c|c|c|c|c|c|c|c|c|c|}
\hline $\mathrm{V}$ & 1 & 2 & 3 & 4 & 5 & 6 & 7 & 8 & 9 & 10 & 11 & 12 & 13 & 14 & 15 & 16 & 17 & 18 & 19 \\
\hline totEI & 1 & & & & & & & & & & & & & & & & & & \\
\hline totES & $.345^{* * *}$ & 1 & & & & & & & & & & & & & & & & & \\
\hline totLs & $.319^{* * *}$ & $.199 * *$ & 1 & & & & & & & & & & & & & & & & \\
\hline EI1 & $.717 * *$ & $.267^{* * *}$ & $.246 * *$ & 1 & & & & & & & & & & & & & & & \\
\hline EI2 & $.880^{* * *}$ & $.291^{* * *}$ & $.281^{* * *}$ & $.630^{* * *}$ & 1 & & & & & & & & & & & & & & \\
\hline EI3 & $.823 * *$ & $.290^{* * *}$ & $.254 * *$ & $.544 * *$ & $.693 * *$ & 1 & & & & & & & & & & & & & \\
\hline EI4 & $.810^{* *}$ & .340 ** & $.269 * *$ & $.492 * *$ & $.649 * *$ & $.609^{* *}$ & 1 & & & & & & & & & & & & \\
\hline EI5 & $.852^{* * *}$ & $.276^{* * *}$ & $.275^{* * *}$ & $.456^{* * *}$ & $.695^{* * *}$ & $.595^{* *}$ & $.618^{* * *}$ & 1 & & & & & & & & & & & \\
\hline EI6 & $.872 * *$ & $.249 * *$ & $.259 * *$ & $.483^{* * *}$ & $.701^{* *}$ & $.647 * *$ & $.637^{* * *}$ & $.823 * *$ & 1 & & & & & & & & & & \\
\hline PC7 & $.250^{* *}$ & $.803^{* * *}$ & $.128 * *$ & $.199 * *$ & $.225^{* *}$ & $.208^{* * *}$ & $.238 * *$ & $.198 * *$ & $.175^{* * *}$ & 1 & & & & & & & & & \\
\hline NC8 & $.286 * *$ & $.810^{* * *}$ & $.078 * *$ & $.215^{* * *}$ & $.219^{* *}$ & $.238^{* * *}$ & $.306^{* * *}$ & $.224 * *$ & $.219^{* * *}$ & $.578 * *$ & 1 & & & & & & & & \\
\hline TS9 & $.273^{* * *}$ & $.798 * *$ & $.190 * *$ & $.205^{* * *}$ & $.227^{* * *}$ & $.251^{* * *}$ & $.265^{* * *}$ & $.224 * *$ & $.182^{* * *}$ & $.513^{* * *}$ & $.516^{* * *}$ & 1 & & & & & & & \\
\hline RSP10 & $.298^{* *}$ & $.802 * *$ & $.235^{* * *}$ & $.239^{* *}$ & $.263^{* *}$ & $.233^{* * *}$ & $.283^{* *}$ & $.238^{* * *}$ & $.223^{* * *}$ & $.499 * *$ & $.524 * *$ & $.533^{* * *}$ & 1 & & & & & & \\
\hline II11 & $.316^{* * *}$ & $.203^{* * *}$ & $.742^{* * *}$ & $.210^{* * *}$ & $.246 * *$ & $.288^{* * *}$ & $.278^{* * *}$ & $.243 * *$ & $.302^{* * *}$ & $.150^{* * *}$ & $.102 * *$ & $.166^{* * *}$ & $.231^{* * *}$ & 1 & & & & & \\
\hline IM12 & $.215^{* * *}$ & $.161^{* * *}$ & $.837 * *$ & $.168^{* * *}$ & $.184^{* * *}$ & $.132 * *$ & $.171^{* * *}$ & $.210^{* * *}$ & $.198^{* * *}$ & $.101^{* * *}$ & $.060^{* * *}$ & $.122^{* * *}$ & $.228 * *$ & $.616^{* * *}$ & 1 & & & & \\
\hline IC13 & $.204^{* *}$ & .140 ** & $.872 * *$ & $.199 * *$ & $.189^{* *}$ & $.141^{* *}$ & $.145^{* *}$ & $.176 * *$ & $.165^{* * *}$ & $.066^{* * *}$ & $.033^{* * *}$ & $.144^{* * *}$ & $.199 * *$ & $.637 * *$ & $.809 * *$ & 1 & & & \\
\hline IS 14 & $.226^{* * *}$ & $.162^{* * *}$ & $.804 * *$ & $.171^{* *}$ & $.241^{* * *}$ & $.193^{* *}$ & $.206^{* * *}$ & $.195^{* * *}$ & $.143^{* * *}$ & $.074 * *$ & $.077^{* * *}$ & $.174^{* * *}$ & $.189^{* * *}$ & $.469 * *$ & $.634^{* *}$ & $.654^{* * *}$ & 1 & & \\
\hline CR15 & $.261^{* * *}$ & $.125 * *$ & $.842 * *$ & $.200^{* * *}$ & $.232^{* * *}$ & $.222 * *$ & $.216^{* * *}$ & $.219^{* *}$ & $.206 * *$ & .087 & .033 & $.138^{* * *}$ & $.141^{* * *}$ & $.566^{* * *}$ & $.614^{* * *}$ & $.706^{* * *}$ & $.713^{* * *}$ & 1 & \\
\hline AM16 & $.272 * *$ & $.164 * *$ & .730 ** & $.193 * *$ & $.239 * *$ & $.205^{* * *}$ & $.241 * *$ & $.266 * *$ & $.203^{* * *}$ & $.129 * *$ & .78 & $.158 * *$ & $.158^{* * *}$ & $.392 * *$ & $.484 * *$ & $.501^{* * *}$ & $.501 * *$ & $.547 * *$ & 1 \\
\hline PM17 & $.296 * *$ & $.158^{* * *}$ & & & $.271^{* * *}$ & $.244 * *$ & $.796 * *$ & $.241 * *$ & $.238 * *$ & $.110^{* * *}$ & .053 & $.163^{* * *}$ & $.176^{* * *}$ & $.499 * *$ & $.566^{* * *}$ & $.612^{* * *}$ & $.553^{* * *}$ & $.604^{* *}$ & $636^{* * *}$ \\
\hline
\end{tabular}

*Correlation is significant at the .05 level. $* *$ correlation is significant at the .01 level.

Website: www.ijreeonline.com, Email: info@ijreeonline.com 
Note. totEI $=$ total emotional intelligence; totEs: total emotional support; totTCL= total teacher classroom leadership; $\mathrm{EI}=$ emotional intelligence; $\mathrm{PC}=$ positive classroom; $\mathrm{NC}=$ negative classroom; $\mathrm{TS}=$ teacher sensitivity, $\mathrm{RSP}=$ regards for students' perspective; $\mathrm{II}=$ idealized influence ; IM=inspirational motivation; $\mathrm{IC}=$ individual consideration ; $\mathrm{IN}=$ intellectual stimulation; $\mathrm{CR}=$ contingent reward; $\mathrm{AM}=$ active management $; \mathrm{PM}=$ passive management .

Analysis of the data indicated that EFL teachers' emotional intelligence and their classroom leadership were positively correlated ( $\mathrm{r}=.319)$. This significant positive correlation is indicated in Table 3 and suggests that there is a relationship between the emotional intelligence and classroom leadership of the EFL teachers. This positive relationship accepts the hypothesis 1 .

Table 3. Teachers' EI and TCL correlation

tot TCL

\begin{tabular}{lll}
\hline tot EI & Pearson correlation & $.319^{* *}$ \\
& Sig(two-tailed) & .000 \\
& $\mathrm{~N}$ & 308
\end{tabular}

**.correlation is significant at the 0.01

Note: totEI: total emotional intelligence; tot TCL: total teacher classroom leadership

Null hypothesis 2 states that there is no significant correlation between EFL teachers' emotional support and classroom leadership. As shown in Table 4, the correlation between EFL teachers' emotional support and their classroom leadership is significant $(\mathrm{r}=.199)$. Therefore, null hypothesis 2 is rejected.

Table 4. Teachers' ES and TCL correlation

tot TCL

\begin{tabular}{lll}
\hline tot Es & Pearson correlation & $.199^{* *}$ \\
& Sig(two-tailed) & .000 \\
$\mathrm{~N}$ & 308 \\
\hline
\end{tabular}

**.correlation is significant at the 0.01

Note: tot Es: total emotional support; tot TCL: total teacher classroom leadership

Null hypothesis 3 asserts that there is no significant correlation between teachers' emotional intelligence and their emotional support. As shown in Table 5, a significant positive correlation was found between teacher emotional intelligence and teacher emotional support $(\mathrm{r}=.345)$. These results reject the null hypothesis 3 . 
Table 5. Teachers' EI and TES correlation

tot ES

\begin{tabular}{ll}
\hline tot EI & $.345^{* *}$ \\
Sig(two-tailed) & .000 \\
$\mathrm{~N}$ & 308
\end{tabular}

**.correlation is significant at the 0.01

Note: tot EI: total emotional intelligence; tot ES: total emotional support.

As it was indicated above, not only were all of the subscales correlated with their scales but also significant correlations were found among them and other scales and subscales of the study. For example, the components of teacher emotional intelligence have a positive significant relationship with the other two variables of the study, teacher emotional support and teacher leadership. It is the same for other variables as well. The seven components of teacher leadership have positively related to teacher emotional intelligence and teacher emotional support. The four components of teacher emotional support have also positively related to the other two variables of the study.

\subsection{Evaluation of the Model}

In order to examine if the proposed theoretical structural model fit the data, the Modification Index (MI) of the goodness-of-fit test was used to revise the relational paths among the variables. All the three indexes of parsimonious fit measurement indicated an adequate model fit, including essential chi- squared=1/637, (p < .001), PGFI $=0.693(>0.50)$, and PNFI $=0.785(>0.50)$. Five additional indexes from incremental fit measurement and absolute fit measurement confirmed the modified model, including IFI $=0.981(>0.90), \mathrm{CFI}=0.981(>0.90), \mathrm{SRMR}=0.031(<0.05)$, $\mathrm{GFI}=0.947(>0.90)$, and RMSEA $=0.041(<0.05)$. The final model fits the data well (Fig 1). According to the final model shown in Fig 1, the positive significant correlation was found between teacher emotional intelligence and teacher emotional support $(\mathrm{r}=0.40)$. In addition, the positive significant correlation was found between teacher emotional intelligence and teacher leadership $(r=0.30)$ and teacher leadership and emotional support $(r=0.10)$. 


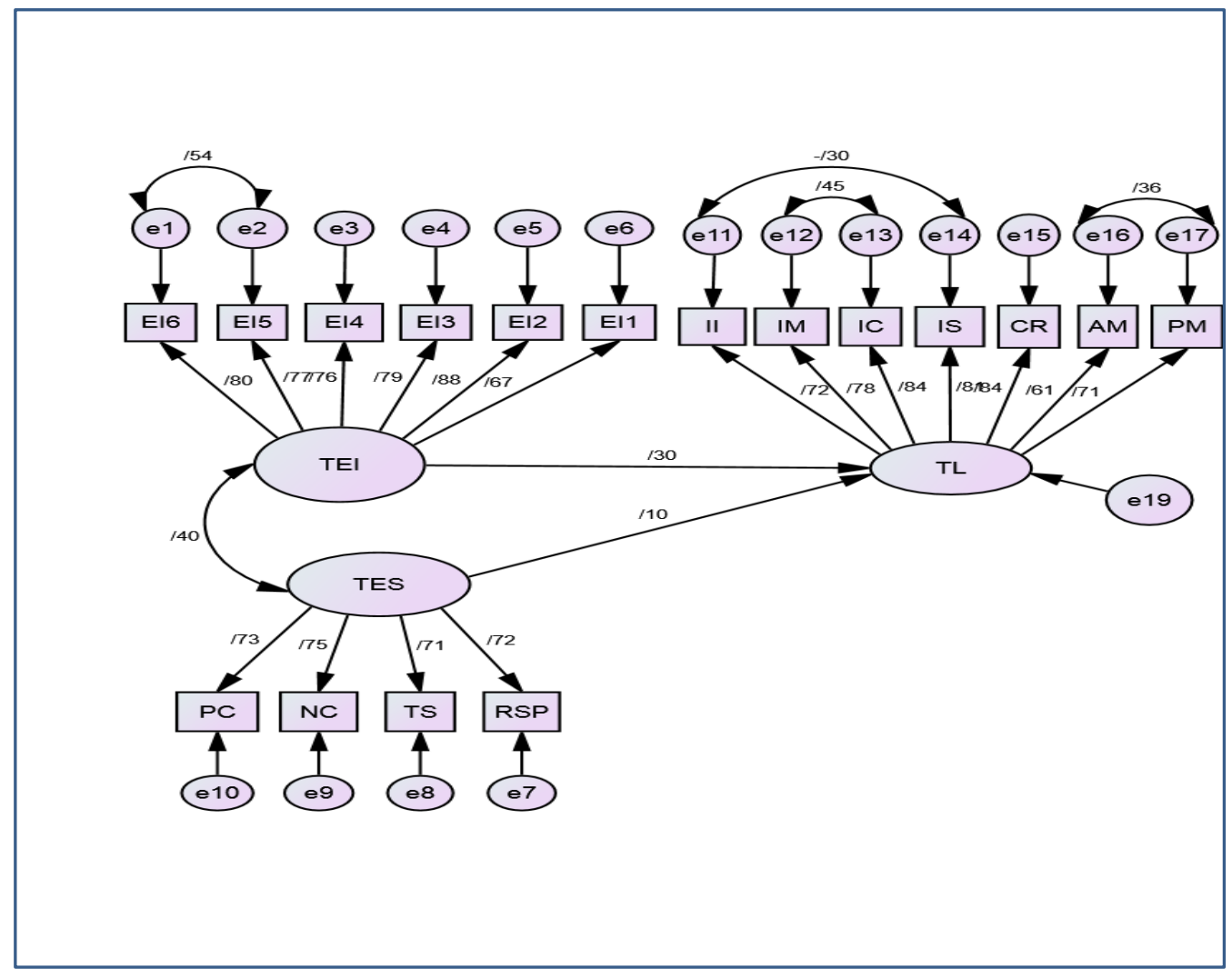

Figure 2. Structural model for the relations between teacher emotional intelligence, teacher emotional support, and teacher classroom leadership, $\mathrm{EI}=$ emotional intelligence, $\mathrm{PC}=$ positive classroom, $\mathrm{NC}=$ negative classroom, $\mathrm{TS}=$ teacher sensitivity, $\mathrm{RSP}=$ regards for students' perspective, $\mathrm{II}=$ idealized influence, $\mathrm{IM}=$ inspirational motivation, $\mathrm{IC}=$ individual consideration, $\mathrm{IN}=$ intellectual stimulation, $\mathrm{CR}=$ contingent reward, $\mathrm{AM}=$ active management, $\mathrm{PM}=$ passive management.

\section{Discussion}

Based on the relevant literature, the purpose of the present study was to examine a model in order to explain the relationships between teacher emotional intelligence, emotional support, and their leadership in ELT classrooms by employing data from 321 EFL teachers in Ilam-Iran. These main variables and their relational paths were identified and confirmed through SEM in the final model. In answering the first question regarding the link between EFL teachers' emotional intelligence and their classroom leadership behavior, a significant correlation was evident $(\mathrm{r}=$ .319). Based on these results, a significant positive correlation was found between transformational leadership and emotional intelligence, but no significant relationship was found between emotional intelligence and transactional leadership.

These findings were in line with Gardner and Stough's (2002) findings. They examined the association between emotional intelligence and transformational, transactional and laissez-faire leadership styles using 110 senior level managers. The results indicated that leaders with transformational behaviors are more effective than leaders with transactional behaviors. A high correlation was found between emotional intelligence and all components of transformational leadership. Iordanoglou (2007) carried out a study to investigate the relationships between emotional intelligence, leadership effectiveness, commitment and satisfaction in education. Using structural equation modeling, they supported the significant role of emotional intelligence in practicing leadership in education. They indicated that the strong correlation between emotional intelligence and the teachers' leadership roles and effectiveness should not be neglected in the teaching profession. They emphasized the important role of teachers in shaping the students' personalities and responsibility in exercising classrooms tasks. In addition, teachers as role models for the students 
can help them to recognize and express their own emotions. A teacher with a high level of emotional intelligence and leadership skills is more likely to have a productive class.

Relating these two concepts to EFL classrooms, teachers would benefit from having a better understanding of the interaction of their emotional intelligence and leadership behaviors, their effects on students. They need to control the class by displaying positive emotions and create a productive environment for students. Teachers with high emotional intelligence are more likely to deal with problems that they may face in the class and provide a supportive environment and enhance the productivity of their class. They are more likely able to lead students and provide appropriate guidance for them. The proposed model confirmed the relationship between the two variables.

The second research question asked about the relationship between EFL teachers' emotional support and classroom leadership. A significant correlation was found $(\mathrm{r}=.199)$ and the null hypotheses that there is no relationship between these variables was rejected. Each of the leadership dimensions was positively and significantly correlated with emotional support, the model confirmed the link between emotional support and leadership. This study extended prior research by proposing a link between these two variables using a more precise analysis approach. Using a multilevel mediation analyses test, Ruzek et al. (2016) carried a study to examine the associations between emotionallysupportive teacher-student interactions and student-reported academic year changes in mastery motivation and behavioral engagement. The findings of their paper showed that teachers with a high level of emotional support enhanced adolescents' academic year, behavioral engagement, and mastery motivation. The reports of mid-year students showed that in emotionally-supportive classrooms, they are more likely to exercise autonomy in doing their activities and develop more positive relationships with their peers.

Students are more likely to be engaged and motivated in emotionally-supportive classrooms. In this classroom, the teacher provides opportunities for students to act autonomously and have positive relationships with their classmates (Ruzek et al., 2016). Hamre and Pianta (2005) conducted a study to find out how teachers may decrease the risk of school failure among children by supporting them. Using 910 children in their study, Hamre and Pianta (2005) found out that children of 5-6 years old are at risk and show behavioral, attention, academic, and social problems as reported by their teachers. Placing them in first-grade classrooms, teachers provided an adequate level of instructional and emotional support which resulted in enhancing students' achievement and improving students' relationship with teachers and peers. While placing them in less supportive classrooms decrease students' achievement and increased more conflict with teachers and peers.

Furthermore, the degree to which teachers support students emotionally in the class decreases the risk of early school failure. In these classrooms, teachers are aware of the different needs of students and constantly respond to their needs. They effectively manage the behavior of students and create a positive classroom climate in which teachers and students enjoy their time spent in the class. Constantly supporting students emotionally in class can enable some students to make academic progress in school. It also moderates the quality of the relationship between teacher and aggressive students who constantly develop conflictual relationships (Hamre \& Pianta, 2005).

The third research question asked about the relation between emotional intelligence and emotional support. A significant correlation was found between teachers' emotional intelligence and emotional support ( $\mathrm{r}=$. 345) that rejected the last null hypothesis of no relationship between these variables. The results of the present study are in line with Atoum and Al-Shoboul (2018). They carried out a study in order to display emotional support from family, teacher, friends, and social medial network, and to examine the relationship between emotional support and emotional intelligence. The findings of their paper indicated a high level of emotional support and showed significant positive relationships between emotional support (teacher, friends, and social medial network) and emotional intelligence.

The results of the present study also showed that different dimension of each scale was positively and significantly correlated with their scale and subscales as well as with other scales and subscales. For example, a positive and significant but weak correlation was found between active management behavior and emotional intelligence ( $\mathrm{r}=.272)$. Analysis of the data found that there was also a positive and significant but weak correlation between passive management and emotional intelligence ( $\mathrm{r}=.296)$.

\section{Conclusion}

This study extended pervious works by investigating the relationship among EFL teacher emotional intelligence, emotional support, and their classroom leadership in an Iranian context. Significant correlations were found among the main variables and their subscales which indicate the important role of these variables in teachers' performance 
and students' learning. The results of the present study provide theoretical and practical implications for educational practitioners and EFL teachers. Since teacher emotional intelligence and emotional support were significantly related to their classroom leadership, it is suggested that educational practitioners consider these characteristics of teachers and provide opportunities for the teacher to be trained in order to understand the importance of these variables in helping students to learn the language more effectively. It is also important for teachers to practice these skills when they are associating with students in classrooms and observe their effects on students' performance. As long as these variables affect students' achievements, it is important for teachers to consider these skills when they teach and attempt to improve them. Considering the interactions of these variables can help teachers to lead their class effectively, deal with the problems that they may face, improve their instruction by applying the effective method of teaching, control students' misbehavior, and provide emotional support for students.

\section{References}

Abraham, R. (2000). The role of job control as a moderator of emotional dissonance and emotional intelligenceoutcome relationships. Journal of Psychology, 134(2), 169-185. doi:10.1080/00223980009600860.

Albrecht, T. L., \& Adelman, M. B. (1987). Communicating social support. Sage Publications, Inc. https://psycnet.apa.org/record/1987-98299-000.

Allen, J., Gregory, A., Mikami, A., Lun, J., Hamre, B., \& Pianta, R. (2013). Observations of effective teacher-student interactions in secondary school classrooms: Predicting student achievement with the classroom assessment scoring system-secondary. School Psychology Review, 42(1), 76-98. https://www.ncbi.nlm.nih.gov > pmc > articles > PMC5602545

Ainsworth, M. D. S., Blehar, M. C., Waters, E., \& Wall, S. N. (2015). Patterns of attachment: A psychological study of the strange situation. Psychology Press. doi.org/10.4324/9780203758045

Atkins, P., \& Stough, C. (2005). Does emotional intelligence change with age? Society for Research in Adult Development annual conference, Atlanta, GA. https://www.researchgate.net

Atoum, A. Y., \& Al-Shoboul, R. A. (2018). Emotional support and its relationship to Emotional intelligence. Advances in Social Sciences Research Journal, 5(1), 7-16. doi: 10.14738/assrj.51.4095

Baba, V. V., \& Ace, M. E. (1989). Serendipity in leadership: Initiating structure and consideration in the classroom. Human Relations, 42(6), 509-525. doi: 10.1177/001872678904200603.

Barchard, K. A., \& Hakstian, A. R. (2004). The nature and measurement of emotional intelligence abilities; Basic dimensions and their relationships with other cognitive abilities and personality variables. Educational and Psychological Measurement, 64(3), 437-462. http://dx.doi.org/10.1177/0013164403261762

Bolkan, S., \& Goodboy, A. K. (2009). Transformational leadership in the classroom: Fostering student learning, student participation, and teacher credibility. Journal of Instructional Psychology, 36(4), 296-306.

Bolkan, S., \& Goodboy, A. K. (2010). Transformational leadership in the classroom: The development and validation of the student intellectual stimulation scale. Communication Reports, 23(2), 91-105. doi: $10.1080 / 08934215.2010 .511399$.

Brackett, M. A., \& Mayer, J. D. (2003). Convergent, discriminant, and incremental validity of competing measures of emotional intelligence. Personality and Social Psychology Bulletin, 29(9), 1147-1158. https://doi.org/10.1177/0146167203254596

Bru, E., Murberg, T. A., \& Stephens, P. (2001). Social support, negative life events, and pupil misbehavior among young Norwegian adolescents. Journal of Adolescence, 24(6), 715-727. doi: 10.1006/jado.2001.0434

Burleson, B. R. (1984). Comforting communication. In H. E. Sypher \& J. L., Applegate (Eds.), Communication by children and adults: Social cognitive and strategic processes, (pp. 63-104). Beverly Hills: Sage Publications.

Burleson, B. R. (2003). The experience and effects of emotional support: What the study of cultural and gender differences can tell us about close relationships, emotion, and interpersonal communication. Personal Relationships, 10(1), 1-23. doi: 10.1111/1475-6811.00033 
Caruso, D. R. (2008). Emotions and the ability model of emotional intelligence. In R. J. Emmerling, V. K. Shanwal, \& M. K. Mandal, M. (Eds.), Emotional intelligence: Theoretical and cultural perspectives, 1-16.

Caruso, D. R., Mayer, J. D., \& Salovey, P. (2003). Emotional intelligence and emotional leadership. Leadership Conference, 9th, Apr 1999, Claremont McKenna Coll, Claremont, CA, US. Lawrence Erlbaum Associates Publishers.

Cheong Cheng, Y. (1994). Teacher leadership style: A classroom-level study. Journal of Educational Administration, 32(3), 54-71. https://doi.org/10.1108/09578239410063111

Ciarrochi, J. V., Chan, A. Y., \& Caputi, P. (2000). A critical evaluation of the emotional intelligence construct. Personality and Individual Differences, 28(3), 539-561. https://doi.org/10.1016/S01918869(99)00119-1

Chan, D. W. (2006). Emotional intelligence and components of burnout among Chinese secondary school teachers in Hong Kong. Teaching and Teacher Education, 22(8), 1042-1054. http://dx.doi.org/10.1016/j.tate.2006.04.005

Christison, M., \& Murray, D. E. (2012). Leadership in English language education: Theoretical foundations and practical skills for changing times. Routledge.

Cutrona, C. E., \& Russell, D. W. (1990). Type of social support and specific stress: Toward a theory of optimal matching. In B. R. Sarason, I. G. Sarason, \& G. R. Pierce (Eds.), Social support: An interactional view (pp. 319-366). Oxford, England: John Wiley \& Sons.

Darling-Hammond, L. (1997). Doing what matters most: Investing in quality teaching. National Commission on Teaching \& America's Future, Kutztown Distribution Center, 15076 Kutztown Road, PO Box 326, Kutztown, PA 19530-0326. https://eric.ed.gov/?id=ED415183

Day, A. L., \& Carroll, S. A. (2004). Using an ability-based measure of emotional intelligence to predict individual performance, group performance, and group citizenship behaviors. Personality and Individual Differences, 36(6), 1443-1458. https://doi.org/10.1016/S0191-8869(03)00240-X

Downer, J. T., López, M. L., Grimm, K., Hamagami, A., Pianta, R. C., \& Howes, C. (2012). Observations of teacherchild interactions in classrooms serving Latinos and dual language learners: Applicability of the Classroom Assessment Scoring System in diverse settings. Early Childhood Research Quarterly, 27(1), 2132. https://doi.org/10.1016/j.ecresq.2011.07.005

Doyle, W. (1986). Classroom organization and management. In M.C. Wittrock (Ed.), Handbook of research in teaching (3rd ed., pp. 392-431). New York: Macmillan.

Ertesvåg, S. K. (2009). Classroom leadership: The effect of a school development programme. Educational Psychology, 29(5), 515-539. https://doi.org/10.1080/01443410903122194

Feyerherm, A. E., \& Rice, C. L. (2002). Emotional intelligence and team performance: The good, the bad and the ugly. The International Journal of Organizational Analysis, 10(4), 343-362. doi: 10.1108/eb028957

Gardner, L., \& Stough, C. (2002). Examining the relationship between leadership and emotional intelligence in seniorlevel managers. Leadership and Organization Development Journal, 23(2), 6878. https://doi.org/10.1108/01437730210419198

George, J. M. (2000). Emotions and leadership: The role of emotional intelligence. Human Relations, 53(8), 10271055. https://doi.org/10.1177/0018726700538001

Goleman, D. (1998). Working with emotional intelligence. Bantam. https://discuss.forumias.com/uploads/FileUpload/7e/04ad5f8607b85facebd440072bfb34.pdf

Good, T. L., \& Brophy, J. (2007). Looking in classrooms (10th ed.). Boston, MA: Allyn \& Bacon.

Hallinger, P. (2003). Leading educational change: Reflections on the practice of instructional and transformational leadership. Cambridge Journal of Education, 33(3), 329-352. doi: 10.1080/0305764032000122005 
Hamre, B. K., \& Pianta, R. C. (2005). Can instructional and emotional support in the first-grade classroom make a difference for children at risk of school failure? Child Development, 76(5), 949-967. https://www.jstor.org/stable/3696607

Harvey, S., Royal, M., \& Stout, D. (2003). Instructor's transformational leadership: University student attitudes and ratings. Psychological Reports, 92(2), 395-402. http://dx.doi.org/10.2466/PR0.92.2.395-402

Hughes, J. N. (2002). Authoritative teaching: Tipping the balance in favor of school versus peer effects. Journal of School Psychology, 40(6), 485-492. http://dx.doi.org/10.1016/S0022-4405(02)00125-5

Hu, L. T., \& Bentler, P. M. (1999). Cutoff criteria for fit indexes in covariance structure analysis: Conventional criteria versus new alternatives. Structural Equation Modeling: A Multidisciplinary Journal, 6(1), 1-55. https://doi.org/10.1080/10705519909540118

Iordanoglou, D. (2007). The teacher as a leader: The relationship between emotional intelligence and leadership effectiveness, commitment, and satisfaction. Journal of Leadership Studies, 1(3), 57-66. doi: 10.1002/jls.20025

Karanja, E., Zaveri, J., \& Ahmed, A. (2013). How do MIS researchers handle missing data in survey-based research: A content analysis approach. International Journal Information Management, 33(5), 734-751. https://doi.org/10.1016/j.ijinfomgt.2013.05.002

Kerr, R., Garvin, J., Heaton, N., \& Boyle, E. (2006). Emotional intelligence and leadership effectiveness. Leadership \& Organization Development Journal, 27(4), 265-279. http://dx.doi.org/10.1108/01437730610666028

Khany, R., Ghasemi, F. (2019). Development and validation of the teacher classroom leadership scale in the EFL context. International journal of leadership in education. doi.org/10.1080/13603124.2019.1591516

Khany, R., \& Ghasemi, F. (2018). Development and validation of teacher emotional support scale: A structural equation modeling approach. Journal of English Language Teaching and Learning. elt.tabrizu.ac.ir/article 7478 b08109c1b79aaf964a5e8d18306a542b.pdf

Khany, R., \& Ghoreyshi, S. M. (2013). On the relationship between Iranian EFL teachers' efficacy of classroom management, reflective thinking, and transformational leadership style: A structural equation modeling. Issues in Language Teaching, 2(1), 55-82. ilt.atu.ac.ir/article_1351_a072fd98ae14a26192def8ab8d57138c.pdf

Leithwood, K. A., \& Jantzi, D. (2006). Transformational school leadership for large scale reform: The effects on students, teachers, and classroom practices. School Effectiveness and School Improvement, 17(2), 201-227. doi: 10.1080/09243450600565829

Luechauer, D. L., \& Shulman, G. M. (2002). Creating empowered learners: A decade trying to practice what we teach. Organization Development Journal, 20(3), 42-50.

Mayer, J. D., \& Salovey, P. (1997). What is emotional intelligence? In P. Salovey, \& D. J. Sluyter (Eds.), Emotional development and emotional intelligence: Educational implications (pp. 3-31). New York, NY.

Merritt, E. G., Wanless, S. B., Rimm-Kaufman, S. E., Cameron, C., \& Peugh, J. L. (2012). The contribution of teachers' emotional support to children's social behaviors and self-regulatory skills in first grade. School Psychology Review, 41(2), 141-159. doi: 10.1037/a0015861

Moafian, F., \& Ghanizadeh, A. (2009). The relationship between Iranian EFL teachers' emotional intelligence and their self-efficacy in Language Institutes. System, 37(4), 708-718. https://doi.org/10.1016/j.system.2009.09.014

Moss, S., Ritossa, D., \& Ngu, S. (2006). The effect of follower regulatory focus and extraversion on leadership behavior: The role of emotional intelligence. Journal of Individual Differences, 27(2), 93-107. https://doi.org/10.1027/1614-0001.27.2.93

Mulaik, S. A., James, L. R., Van Alstine, J., Bennett, N., Lind, S., \& Stilwell, C. D. (1989). Evaluation of goodnessof-fit indices for structural equation models. Psychological Bulletin, 105(3), 430. (3), 430-445. doi: 10.1037/0033-2909.105.3.430

Murray, D. E., \& Christison, M. (2008). The role of emotional intelligence in ELT leadership. Leadership in English Language Education: Theoretical Foundations and Practical Skills for Changing Times, 85. 
Ojode, L. A., Walumbwa, O., \& Kuchinke, P. (1999). Developing human capital for the evolving work environment: Transactional and transformational leadership within an instructional setting. In the annual conference of the Midwest Academy of Management, April (pp. 16-17).

Patrick, H., Anderman, L. H., \& Ryan, A. M. (2002). Social motivation and the classroom social environment. Goals, goal structures, and patterns of adaptive learning, 85-108. Mahwah, NJ, US: Lawrence Erlbaum Associates Publishers.

Perry, C., Ball, I., \& Stacey, E. (2004). Emotional intelligence and teaching situations: Development of a new measure. Issues in Educational Research, 14(1), 29-43. http://www.iier.org.au/iier14/perry.html

Pianta, R. C., Belsky, J., Houts, R., Morrison, F. (2007). Opportunities to learn in America's elementary classrooms. Science, 315(5820), 1795-1796. doi: 10.1126/science.1139719

Pianta, R., Howes, C., Burchinal, M., Bryant, D., Clifford, R., Early, D., \& Barbarin, O. (2005). Features of prekindergarten programs, classrooms, and teachers: Do they predict observed classroom quality and child-teacher interactions? Applied Developmental Science, 9(3), 144-159. https://doi.org/10.1207/s1532480xads0903_2

Pianta, R. C., \& Hamre, B. K. (2009). Conceptualization, measurement, and improvement of classroom processes: Standardized observation can leverage capacity. Educational Researcher, 38(2), 109-119. https://doi.org/10.3102/0013189X09332374

Pierce, G. R., Sarason, B. R., \& Sarason, I. G. (1996). Handbook of social support and the family. Springer Science \& Business Media.

Pink, D. (2005). A whole new mind: Moving from the information age to the conceptual age. Riverhead, New York, NY.

Pounder, J. S. (2003). Employing transformational leadership to enhance the quality of management development instruction. Journal of Management Development, 22(1), 6-13. https://doi.org/10.1108/02621710310454824

Pounder, J. S. (2006). Transformational classroom leadership: The fourth wave of teacher leadership? Educational management administration \& leadership, 34(4), 533-545. doi:10.1177=1741143206068216

Pounder, J. S. (2008). Full-range classroom leadership: Implications for the cross-organizational and cross-cultural applicability of the transformational-transactional paradigm. Leadership, 4(2), 115-135. https://doi.org/10.1177/1742715008089634

Prati, L., Douglas, C., Ferris, G. R., Ammeter, A. P., \& Buckley, M. R. (2003). Emotional intelligence, leadership effectiveness, and team outcomes. The International Journal of Organizational Analysis, 11(1), 21-40. https://doi.org/10.1108/eb028961

Radi, fawqiah. (2002). Emotional intelligence and its relation to academic achievement and the ability of innovative thinking among university students. Journal of the Faculty of Education, 45(4).

Richards, J. C., \& Lockhart, C. (1994). Reflective teaching in second language classrooms. Cambridge University Press.

Roland, E. (1999). School influences on bullying. Stavanger, Norway: Rebell Forlag.

Rosete, D., \& Ciarrochi, J. (2005). Emotional intelligence and its relationship to workplace performance outcomes of leadership effectiveness. Leadership \& Organization Development Journal, 26(5), 388-399. doi: $10.1108 / 01437730510607871$

Roeser, R. W., Eccles, J. S., \& Sameroff, A. J. (1998). Academic and emotional functioning in early adolescence: Longitudinal relations, patterns, and prediction by experience in middle school. Development and Psychopathology, 10(2), 321-352. doi: https://doi.org/10.1017/S0954579498001631

Ruzek, E. A., Hafen, C. A., Allen, J. P., Gregory, A., Mikami, A. Y., \& Pianta, R. C. (2016). How teacher emotional support motivates students: The mediating roles of perceived peer relatedness, autonomy support, and competence. Learning and Instruction, 42, 95-103. doi:10.1016/j.learninstruc.2016.01.004 
Ryan, R. M., \& Deci, E. L. (2000). Self-determination theory and the facilitation of intrinsic motivation, social development, and well-being. American Psychologist, 55(1), 68-78. doi: 10.1037/0003-066X.55.1.68

Salovey, P., \& Mayer, J. D. (2007). Emotional intelligence. In P. Salovey, M. A .Brackett, \& J. D. Mayer (Eds.), Emotional intelligence: Key readings on the Mayer and Salovey model (pp. 1-28). Port Chester, New York: Dude Publishing.

Salovey, P., \& Mayer, J. D. (1990). Emotional intelligence. Imagination, cognition, and personality, 9(3), 185-211. https://doi.org/10.2190/DUGG-P24E-52WK-6CDG

Schaie, K. W. (2001). Emotional intelligence: Psychometric status and developmental characteristics--Comment on Roberts, Zeidner, and Matthews (2001). Emotion, 1(3), 243-248. http://dx.doi.org/10.1037/1528-3542.1.3.243

Schutte, N. S., \& Malouff, J. M. (1998). Measuring emotional intelligence and related constructs. Levinston: Mellen Press.

Schutte, N. S., Malouff, J. M., Hall, L. E., Haggerty, D. J., Cooper, J. T., Golden, C. J., \& Dornheim, L. (2001). Development and validation of a measure of emotional intelligence. Personality and individual differences, 25(2), 167-177. https://doi.org/10.1016/S0191-8869(98)00001-4

Shaw, B. A., Krause, N., Chatters, L. M., Connell, C. M., \& Ingersoll-Dayton, B. (2004). Emotional support from parents early in life, aging, and health. Psychology and Aging, 19(1), 4-12. doi:10.1037/0882-7974.19.1.4

Skinner, E. A., \& Belmont, M. J. (1993). Motivation in the classroom: Reciprocal effects of teacher behavior and student engagement across the school year. Journal of Educational Psychology, 85(4), 571-581. doi: 10.1037/0022-0663.85.4.571

Thuen, E. (2007). Learning environment students' coping styles and emotional and behavioral problems: A study of Norwegian secondary school students. Doctoral Thesis. University of Bergen, Bergen, Norway.

Ukaegbu, M. H. M. (2015). Emotional, social, cognitive intelligence and social support network among youths. British Journal of Physical Research, 3(2), 35-41.

Van Rooy, D. L., Alonso, A., \& Viswesvaran, C. (2005). Group differences in emotional intelligence scores: Theoretical and practical implications. Personality and Individual Differences, 38(3), 689-700. http://dx.doi.org/10.1016/j.paid.2004.05.023

Wallace, M. (1994). Training foreign language teachers: A reflective approach. Cambridge: Cambridge University Press.

Walumbwa, F. O., \& Ojode, L. A (2000). Gender stereotype and instructors' leadership behavior: Transformational and transactional leadership. Midwest Academy of Management Annual Conference at Chicago, March 30thApril 1st.

Walumbwa, F. O., Wu, C., \& Ojode, L. A. (2004). Gender stereotype and instructors leadership behavior: Transformational and transactional leadership. Midwest Academy of Management Annual Conference and instructional outcomes: The mediating role of leadership style. Journal of Management Development, 23(2), 124-140. https://doi.org/10.1108/02621710410517229

Wentzel, K. R. (1999). Social-motivational processes and interpersonal relationships: Implications for understanding motivation at school. Journal of Educational Psychology, 91(1), 76-97. http://dx.doi.org/10.1037/0022$\underline{0663.91 .1 .76}$

Wilmore, E. L. (2007). Teacher leadership: Improving teaching and learning from inside the classroom. Thousand Oaks, CA: Corwin Press.

Wolff, S. B., Pescosolido, A. T., \& Druskat, V. U. (2002). Emotional intelligence as the basis of leadership emergence in self-managing teams. The Leadership Quarterly, 13(5), 505-522. https://doi.org/10.1016/S1048$\underline{9843(02) 00141-8}$ 
Wong, C. S., \& Law, K. S. (2002). The effects of leader and follower emotional intelligence on performance and attitude: An exploratory study. The Leadership Quarterly, 13(3), 243-274. https://doi.org/10.1016/S10489843(02)00099-1

Yeung, R., \& Leadbeater, B. (2010). Adults make a difference: the protective effects of parent and teacher emotional support on emotional and behavioral problems of peer-victimized adolescents. Journal of Community Psychology, 38(1), 80-98.

Zhou, J., \& George, J. M. (2003). Awakening employee creativity: The role of leader emotional intelligence. [Electronic version]. The Leadership Quarterly, 14(4-5), 545-568. https://doi.org/10.1016/S10489843(03)00051-1 